\title{
47. INTRODUCTION TO THE BAJA CALIFORNIA PASSIVE-MARGIN-TRANSECT SYMPOSIUM ${ }^{1}$
}

\author{
Joseph R. Curray and David G. Moore, Scripps Institution of Oceanography, La Jolla, California
}

DSDP Leg 64, although dedicated in general to drilling in the Gulf of California, was concentrated in three specific areas of the Gulf, each of which is associated with a topical research problem. The shipboard scientific party decided after the cruise that the Initial Reports volume for the leg should be organized in such a way as to segregate the synthesis papers on these three regions into separate symposia. The papers in this section or "symposium," therefore, treat the principal results of drilling during the Baja California passive-margin transect.

We have reviewed evolutionary models for formation of passive or intraplate continental margins (Moore and Curray, this volume, Pt. 1.). The Deep Sea Drilling Project previously had drilled primarily in the oceanic environment, away from continental margins, with only a limited amount of drilling in older continental margins, either starved or mature (Moore and Curray, this volume, Pt. 1). The advantages of drilling in a young passive margin are that subsidence has not progressed as far, and sedimentation has not deeply buried continen-

\footnotetext{
${ }^{1}$ Curray, J. R., Moore, D. G., et al., Init. Repts. DSDP, 64: Washington (U.S. Govt. Printing Office).
}

tal basement rocks, the rift environments, and the transition to oceanic crust. This transect in the Gulf of California is the Project's first encounter with such a young passive continental margin, and it is also the first close delineation of the transition from continental to oceanic crust.

This three-site transect (Figs. 1 and 2) was placed off the tip of Baja California because this younger margin appears to be a typical listric, or block-faulted, passive margin. Earlier geological and geophysical work had shown trends of the faulting approximately parallel to the oceanic spreading axis of the East Pacific Rise, with an opportunity for narrowly delineating the transition from continental to oceanic crust. In brief, the drilling showed a thick section of predominantly turbidite sedimentation over the oldest oceanic crust at the foot of the continental slope, closely adjacent to predominantly hemipelagic sediment overlying deeply subsided granitic rocks of the tip of Baja California. The late Pliocene age of the oldest marine sediments overlying the oldest oceanic crust confirms previous determinations of age of spreading from study of magnetic anomalies.

These results will be further elaborated in the following collection of papers. 


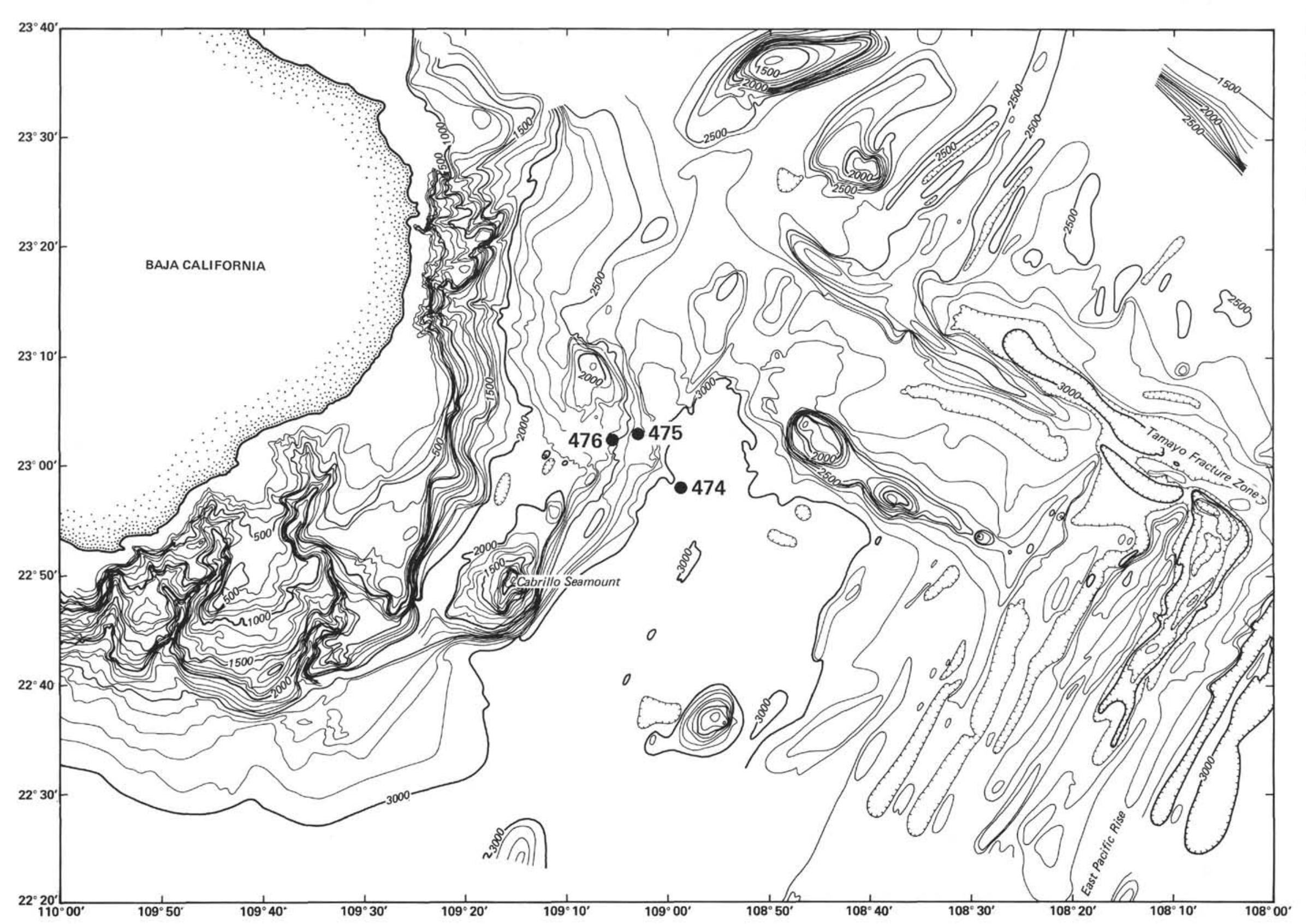

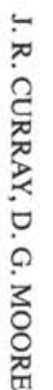

Figure 1. Regional bathymetry of the Baja California passive-margin transect (contours are in uncorrected meters, assuming $1500 \mathrm{~m} / \mathrm{s}$; drilling sites are also shown). 

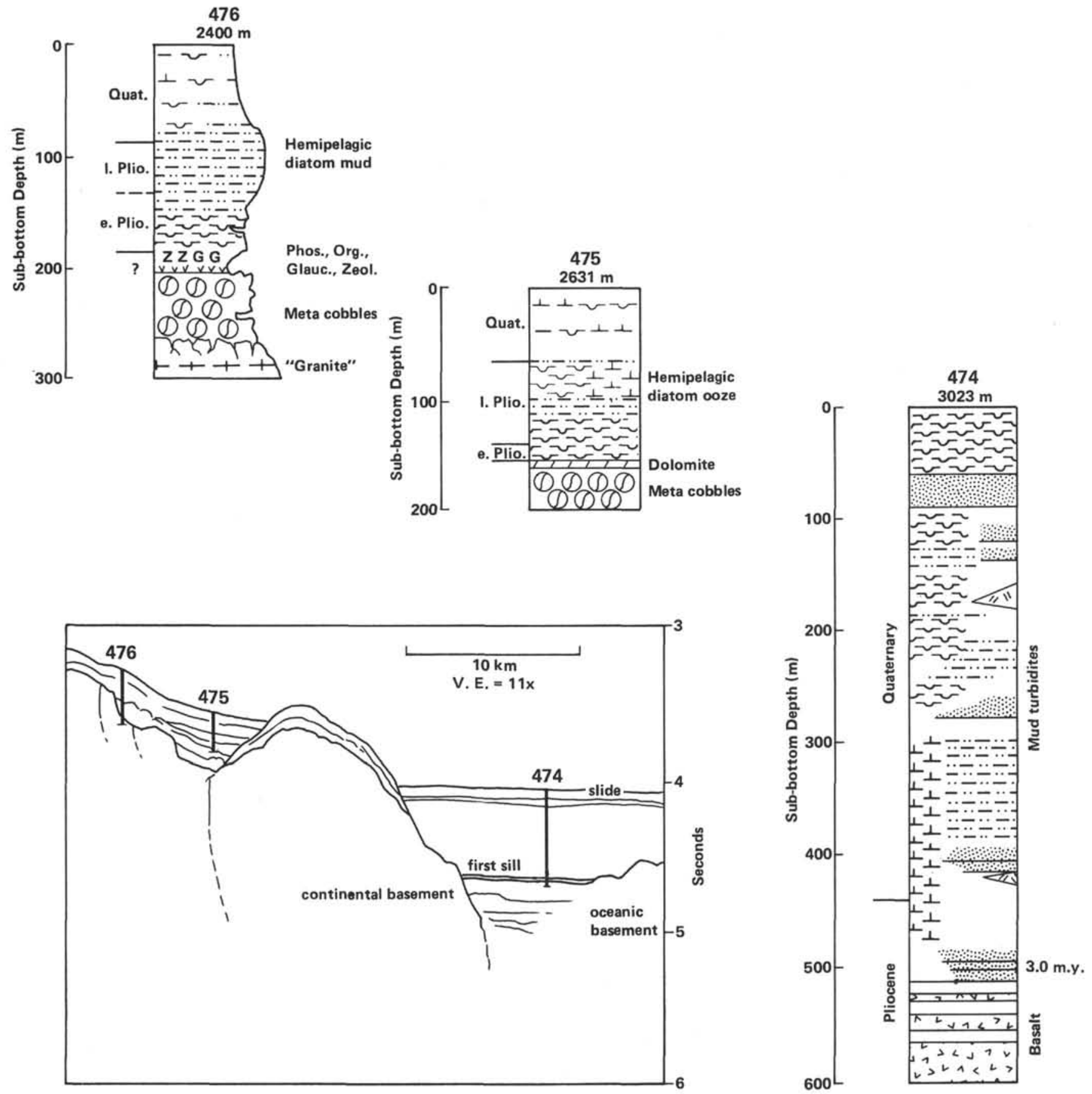

Figure 2. Simplified principal lithologic results and line drawing through Baja California passive-margin transect. 